\title{
Synthesis and Characterization of Ni-WO3/Sulfated Zirconia Nano catalyst for Isomerization of N-Hexane and Iraqi Light Naphtha
}

\author{
Safa Abdul Salam Kamel, Wadood Taher Mohammed, and Haider A. Al-Jendeel
}

Chemical Engineering Department/University of Baghdad/Baghdad, Iraq

\begin{abstract}
This work deals with the preparation of Sulfated Zirconia catalyst (SZ) for isomerization of n-hexane model and refinery light naphtha, as well as enhanced the role of promoters to get the target with the mild condition, stability, and to prevent the formation of coke precursors on strong acidic sites of the catalyst. The prepared $\mathrm{Ni}-\mathrm{WO}_{3} / \mathrm{Sulfated}$ Zirconia catalyst was characterized by Fourier transform infrared spectroscopy (FTIR), X-ray diffraction (XRD), Brunauer -Emmett-Teller (BET) surface area analysis, Thermogravimetric Analysis (TGA), and atomic force microscopy (AFM) Analyzer. The results illustrate that the maximum conversion and selectivity for n-hexane isomerization with Ni-WSZ at the operating temperature of $150{ }^{\circ} \mathrm{C}$ was $80.1 \%$ and $96 \%$ respectively. While the experimental with light naphtha, the results show that the maximum conversion and selectivity with Ni-WSZ at the operating temperature of $150{ }^{\circ} \mathrm{C}$ was $53 \%$ and $74 \%$ respectively.
\end{abstract}

Keywords: Light naphtha isomerization, n-hexane, Nickel-tungsten, Sulfated Zirconia, Super acidic catalyst, isomerization process

Received on 07/11/2021, Accepted on 19/12/2021, published on 30/12/2021

https://doi.org/10.31699/IJCPE.2021.4.1

\section{1- Introduction}

Pollution and climate change have made the world more attentive and concerned about the environment in the last few decades. At the same time, the industrial processes in general and oil refinery, in particular, have touched the growing of fuel demand and quality for the combustion engine efficiency of fuel by the research octane number $(\mathrm{RON})$. The distillation of petroleum fractions in the oil refinery industry cannot meet the required properties of gasoline with RON 92 to 100 as needed by modern engines [1].

In the past, as a result, to increase the octane number, many approaches were adopted like adding some addition, this was achieved using lead compounds, i.e., tetraethyl lead that became restricted and prohibited later due to environmental regulation as they are toxic and poison exhaust gas converters. Another technique was adopted to enhance the RON is by mixing the fuel with benzene and/or other aromatics, also, the legislation of the acceptable degree of these aromatics in fuel is becoming stricter later, on the other hand, Methyl Tetra butyl ether (MTBE) has been related to groundwater pollution, although being less hazardous than lead. Simultaneously, some of the high-octane components found in gasoline, such as benzene, aromatics, and olefins, must be decreased as well. It will be better to use a technique that will improve the octane of gasoline without adding hazardous or ecologically harmful chemicals [2].
So the oil industry has turned to the modern alternative processes that use catalysts to convert the straight chainalkanes to branched alkanes which have higher octane numbers sufficient to raise the octane rating of gasoline, this is called the isomerization process[3].

Hydroisomerization processes frequently necessitate the use of dual-purpose catalysts. With the help of noble metals like platinum and palladium an acid site, a bifunctional catalyst performs two functions: hydrogenation/dehydrogenation and cracking[4]. Because of the thermodynamics of isomerization, lower reaction temperatures favor the generation of isoparaffins, hence catalysts that operate at low temperatures are often more selective to isomers than those that operate at high temperatures $[5,6]$.

Because of their high acidity and low reaction temperature (about $180^{\circ} \mathrm{C}$ ), platinum-loaded chlorinated alumina catalysts were initially used in industrial isomerization units. However, there are several disadvantages to using this type of catalyst. There are numerous corrosion and environmental issues associated with the use of chlorine in catalyst regeneration [7]. The long life of the $\mathrm{Pt} / \mathrm{Cl}-\mathrm{Al}_{2} \mathrm{O}_{3}$ catalyst necessitates the use of feed and make-up gas driers for the removal of moisture. So there's a strong incentive to find a better, less harmful catalyst for n-alkane isomerization to increase the production of isomerate. Zeolites and SZ are examples of potential catalysts for $n$-alkane isomerization that have been proposed in the literature. 
Low reaction temperature favors n-alkane isomerization since it is a mildly exothermic process. Catalysts that are active between $(100-200)^{0} \mathrm{C}$ are thought to be the most appropriate for $\mathrm{C}_{4}-\mathrm{C}_{6}$ isomerization. Despite numerous tries, zeolite catalysts are no longer thermodynamically advantageous for n-alkane isomerization from this point on. zeolite catalysts must be run at a higher temperature, typically $200^{\circ} \mathrm{C}$ to $300^{\circ} \mathrm{C}$. Finally, compared to the $\mathrm{Pt} / \mathrm{Cl}$ $\mathrm{Al}_{2} \mathrm{O}_{3}$ catalyst, the SZ-based catalysts exhibit satisfactory catalytic performance in n-alkane isomerization [8]. Because of their high activity, simplicity of handling, and absence of corrosiveness, these catalysts are considered promising industrial catalysts. [9].

The addition of several transition metals to sulfated zirconia, such as Pt, Pd [10], Fe, and Mn [8], has been shown to increase the catalytic activity and stability against rapid deactivation. However, $\mathrm{Ma}$ et al. [11] demonstrated that $\mathrm{Ni}$ impairs the catalytic efficiency of sulfated zirconia. Ni significantly altered the total acidity and concentration of strong acid sites; $\mathrm{Ni}$ was utilized in place of $\mathrm{Pt}$ as the active metal phase of various acid solids, and the resulting catalysts were evaluated in hydrocarbon processes. $\mathrm{Ni}$ is less expensive than noble metals such as $\mathrm{Pt}$ or $\mathrm{Pd}$, thus its use would be costeffective [11]. Additionally, modification of SZ with additional anions, such as $\mathrm{WO}_{3}$ might result in the formation of strong acid sites on the zirconia surface that are extremely stable[12].

The investigation aims to develop more efficient catalysts consists sulfated zirconia as a based catalyst supported with $\mathrm{WO}_{3}, \mathrm{Ni}$ to improve the isomerization of $\mathrm{N}-\mathrm{Hexane}$ and Iraqi Light Naphtha and to examine in detail the effect of the reaction condition on catalytic activity.

\section{2- Experimental Work}

\subsection{Feedstock}

Midland Refineries Company/Al-Dura refinery terminal supplied Light naphtha utilized as feed to isomerization unit for activity test. Physical Properties and composition of the light naphtha listed in Table $\mathbf{1}$

Table 1. Physical Properties and composition of. light.naphtha

\begin{tabular}{ll}
\hline Physical properties & Value \\
\hline Density & $0.664 \mathrm{~g} / \mathrm{cm}^{3}$ \\
Initial boiling point & $36{ }^{\circ} \mathrm{C}$ \\
End boiling point & $84^{\circ} \mathrm{C}$ \\
Sulfur content & $1.6 \mathrm{ppm}$ \\
Octane number & 60 \\
n-Paraffin & $56.33 \mathrm{wt} \%$ \\
i-Paraffin & $30 \mathrm{wt} . \%$ \\
Naphthene & $6.78 \mathrm{wt} \%$ \\
Aromatic & $4 \mathrm{wt} . \%$ \\
\hline
\end{tabular}

\subsection{Chemicals Used}

Table 2 shows the chemicals used with its specifications:

Table 2. chemical compounds Specifications

\begin{tabular}{lllll}
\hline Chemicals & Formula & Density & $\begin{array}{l}\text { Molecular weight } \\
(\mathrm{g} / \mathrm{gmol})\end{array}$ & Purity \\
\hline $\begin{array}{l}\text { Zirconum } \\
\text { oxychloride } \\
\text { octahydrate }\end{array}$ & $\mathrm{ZrOCl}_{2} .8 \mathrm{H}_{2} \mathrm{O}$ & $\begin{array}{l}1.910 \\
\mathrm{~g} / \mathrm{ml}\end{array}$ & 322.25 & $99 \%$ \\
$\begin{array}{l}\text { Ammonia solution } \\
\text { Sulfuric acid }\end{array}$ & $\mathrm{NH}_{3}$ aq. & $0.91 \mathrm{~g} / \mathrm{ml}$ & 17.03 & $25 \%$ \\
$\begin{array}{l}\text { Nickel (II) nitrate } \\
\text { hexahydrate }\end{array}$ & $\begin{array}{l}\mathrm{H}_{2} \mathrm{SO}_{4} \\
\mathrm{O}(\mathrm{NO} 3)_{2} \cdot 6 \mathrm{H}_{2}\end{array}$ & $1.83 \mathrm{~g} / \mathrm{ml}$ & 98.08 & $98 \%$ \\
$\begin{array}{l}\text { ammonium } \\
\text { meta tungsten }\end{array}$ & $\begin{array}{l}2.05 \mathrm{~g} / \mathrm{ml} \\
\left(\mathrm{NH}_{4}\right)_{6} \mathrm{H}_{2} \mathrm{~W}_{12} \mathrm{O}\end{array}$ & $4.6 \mathrm{~g} / \mathrm{ml}$ & 290.81 & $98 \%$ \\
nanoalumina & $\mathrm{Al}_{2} \mathrm{O}_{3}$ & $3.95 \mathrm{~g} / \mathrm{ml}$ & 101.96 & $91 \%$ \\
$\begin{array}{l}\text { Poly Vinyl } \\
\text { Alcohol }\end{array}$ & $\left(\mathrm{CH}_{2} \mathrm{CHOH}_{2}\right) \mathrm{n}$ & $1.19 \mathrm{~g} / \mathrm{ml}$ & 1750 & w \\
n-hexane & $\mathrm{C}_{6} \mathrm{H}_{14}$ & 0.655 & 86.18 & 99.99 \\
Bentonite & $\mathrm{AL}_{2} \mathrm{O}_{3} \cdot 4\left(\mathrm{SiO}_{2}\right)$. & $2 \sim 3 \mathrm{~g} / \mathrm{cm}^{3}$ & 360.31 & $99 \%$ \\
\hline
\end{tabular}

\subsection{Preparation of Catalyst}

$150 \mathrm{~g}$ of Zirconium Oxy-chloride salt $\left(\mathrm{ZrOCl}_{2} \cdot 8 \mathrm{H}_{2} \mathrm{O}\right)$ was dissolved in $2000 \mathrm{ml}$ of deionized water and ammonia solution of about $25 \%$ concentration added drop by drop above the solution above under vigorous stirring until the Ph of the slurry reached (8), keeping the slurry for extra time of about $0.5 \mathrm{hr}$ and aged it at room temperature for $16 \mathrm{hr}$ to allow zirconium hydroxide $\mathrm{Zr}(\mathrm{OH})_{4}$ enough time to precipitate. Then, the precipitate of zirconium hydroxide was filtered under vacuum condition, washed with the access of deionized water to remove chlorine ions and get acidity of about 7 , drying the sample at $100{ }^{\circ} \mathrm{C}$ for $15 \mathrm{hr}$. Thereafter, hydrous zirconia was grounded to a fine powder and the Sulfation process was carried out by wet-impregnating the sample with $\mathrm{H}_{2} \mathrm{SO}_{4}$ of $1 \mathrm{~mol} / \mathrm{l}$ at $2 \mathrm{ml} / \mathrm{g}$ for $1 \mathrm{hr}$, , then, submit the sulfated zirconia produced to dried at $100{ }^{\circ} \mathrm{C}$ for $15 \mathrm{hr}$ by the digital dryer and calcined at $600{ }^{\circ} \mathrm{C}$ for $3 \mathrm{hr}$ [13].

The Wet-impregnation method was adopted to add nickel and tungsten promoters. Firstly, SZ was impregnated with an aqueous solution of nickel nitrate $\left(\mathrm{Ni}\left(\mathrm{NO}_{3}\right)_{2} \cdot 6 \mathrm{H}_{2} \mathrm{O}\right)$ as shown in Fig. 1, to prepare $1 \% \mathrm{Ni}$ SZ catalyst which was dried at $110^{\circ} \mathrm{C}$ and calcined at $450^{\circ} \mathrm{C}$ in the air for $3 \mathrm{hr}$. thereafter, an aqueous solution of ammonium metatungstate $\left(\left(\mathrm{NH}_{4}\right)_{6}\left(\mathrm{H}_{2} \mathrm{~W}_{12} \mathrm{O}_{40} \cdot \mathrm{nH}_{2} \mathrm{O}\right)\right.$ was used to impregnate $\mathrm{Ni} / \mathrm{SZ}$ catalyst by dropwise mechanism to load $25 \% \mathrm{WO}_{3}$ on it. Then, the produced catalyst was left for $24 \mathrm{hr}$ at room temperature and then dried overnight at $110{ }^{\circ} \mathrm{C}$ and calcined in air at $700{ }^{\circ} \mathrm{C}$ for $3 \mathrm{hr}$. Finally was extruded the catalyst by mixed with $20 \%$ Nano alumina, $10 \%$ bentonite, and $7 \%$ polyvinyl alcohol solution (PVA) as binders with $(0.65 \mathrm{~cm}$ length and 0.12 $\mathrm{cm}$ diameter) as shown in Fig. 2, a by Formulating machine of catalyst as shown in Fig. 2, b. 


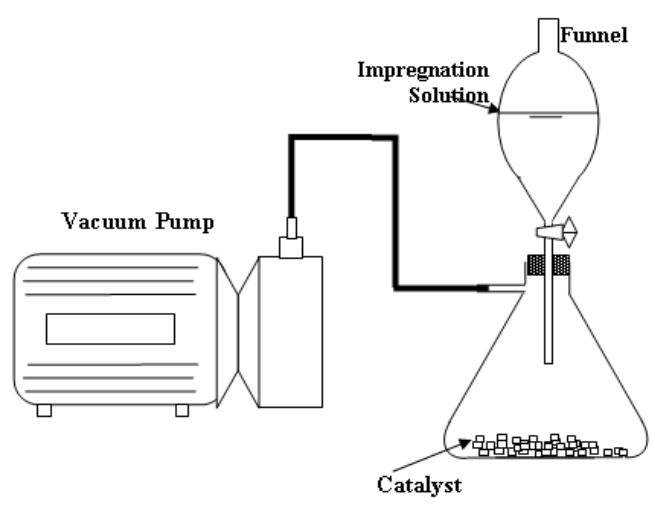

Fig. 1. Scheme of impregnation apparatus

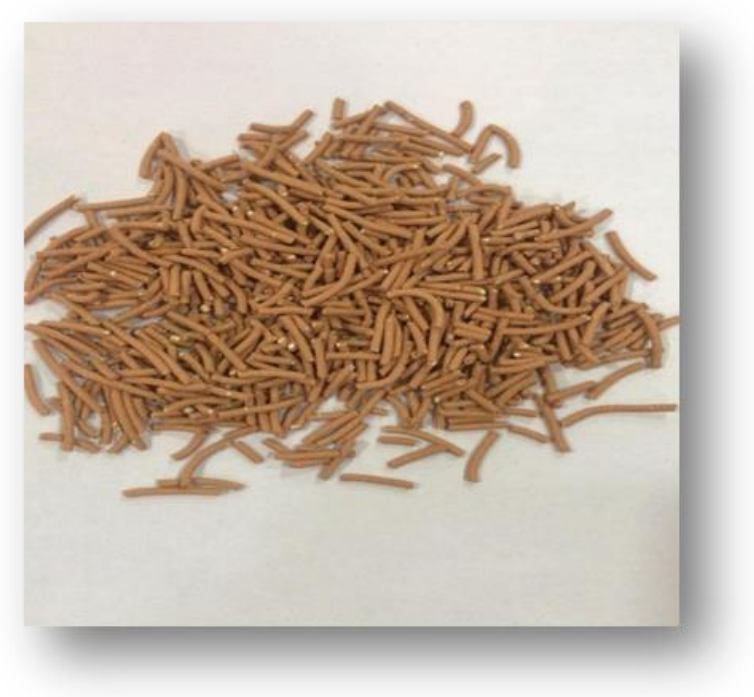

(a)

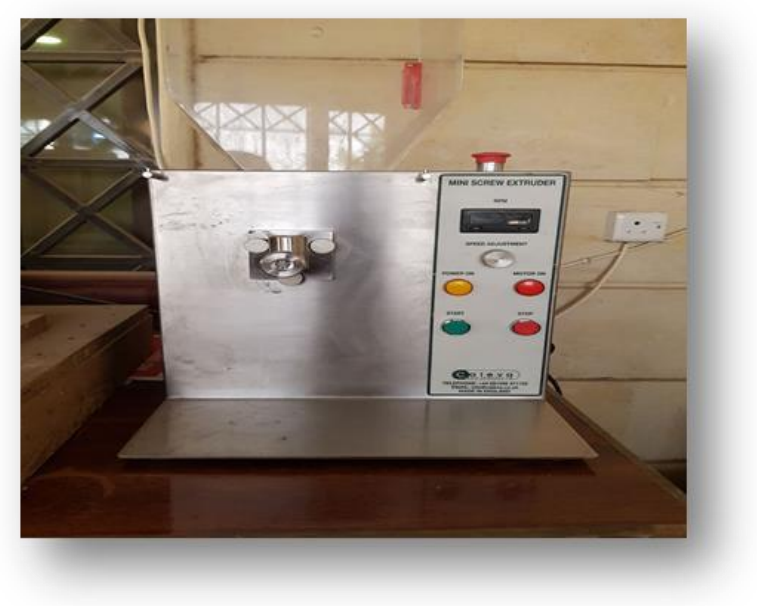

(b)

Fig. 2. a. Catalyst formation extruded of powder $\mathrm{Ni}-\mathrm{WO}_{3} /$ SZ, b. Formulating machine of catalyst

\subsection{Catalytic Activity Test}

$7 \mathrm{~g}$ of $\left(\mathrm{Ni}-\mathrm{WO}_{3} / \mathrm{SZ}\right)$ catalyst was used in a fixed bed reactor in its designated area of the reactor between two layers of inert ceramic balls material of about $5 \mathrm{~mm}$ diameter to ensure a uniform flow and an effective surface area for the catalysts. In the beginning, the nitrogen is passed into the reactor to release the air from the system. At the same time, the reactor is heated to the temperature required for that experiment. And at this moment, the nitrogen passage valve is closed and the reactor is feeding with n-hexane model fuel (or light naphtha) through dosing pump and hydrogen through the control valve, which they mixed in the zone ahead of the experimental reactor. The mixture will pass over the catalyst in the reactor and the reaction will occur. The product of the reactor will be cooled by a refrigerant system and the hydrogen will be separated by a highpressure separator. At the steady-state operation, the product of the reactor will be sent to the Gas Chromatography Analyzer (GC). The isomerization unit is represented in Fig 3 The reaction conditions for isomerization of n-hexane (or light naphtha) are shown in Table 3 below:

Table 3. Operating condition of $n$-hexane isomerization process

\begin{tabular}{ll}
\hline feed & n-hexane or light Naphtha \\
\hline Catalysts used are & $\mathrm{Ni}-\mathrm{WO}_{3} / \mathrm{SZ}$ or $\mathrm{Pd}-\mathrm{WO}_{3} / \mathrm{SZ}$ \\
Reaction temperature & $120 \mathrm{C}-250 \mathrm{C}$ \\
Operating pressure & $6 \mathrm{bar}$ \\
Mole ratio of H2/HC & 4 \\
Liquid hour space velocity ( & $1 \mathrm{hr}^{-1}$ \\
LHSV) & \\
\hline
\end{tabular}

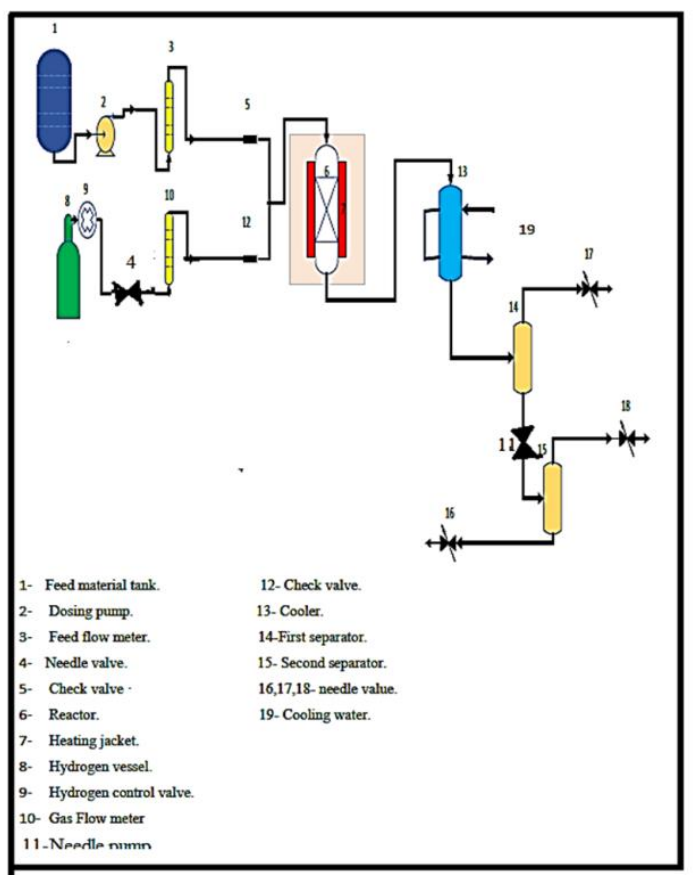

(a) 


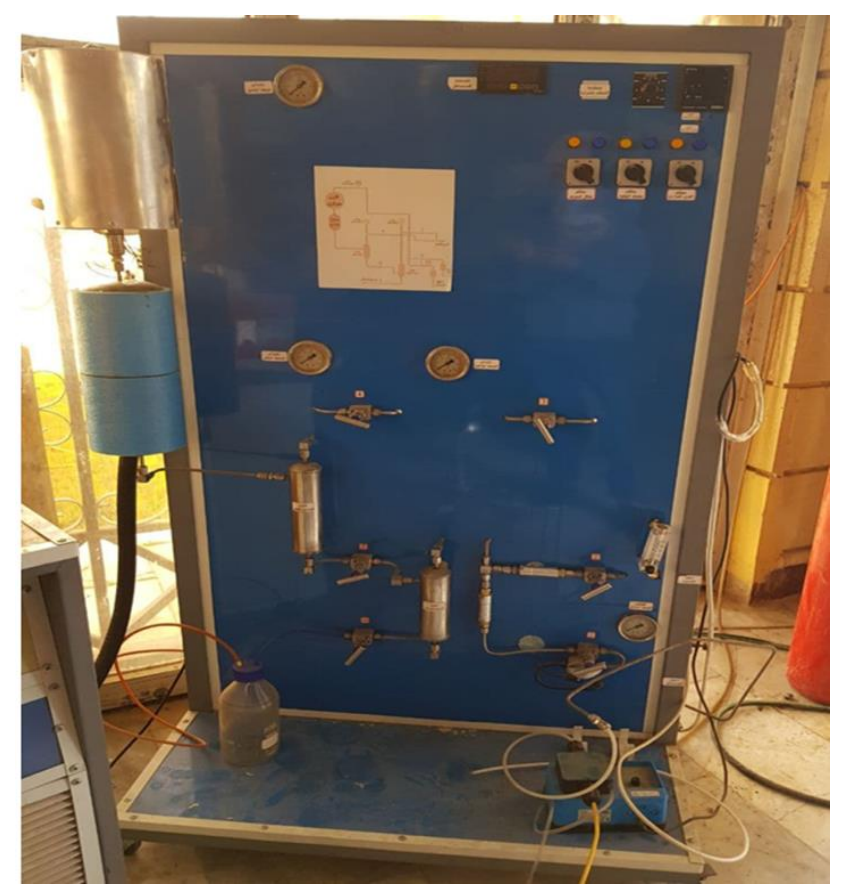

(b)

Fig. 3. . Isomerization process, a. schematic representation of isomerization unit, b. Isomerization Unit

\section{3- Characterization of Synthesized Catalysts}

The first part of this study is represented by preparing $\mathrm{Ni} / \mathrm{WO}_{3}-\mathrm{SZ}$ catalyst by two steps (precipitationimpregnation method) and characterizing it for isomerization of Iraqi light naphtha and n-hexane. This characterization includes; X-ray diffraction (XRD), Fourier Transform Infrared FTIR spectroscopic, atomic force microscope (AFM).

\subsection{X-ray Diffraction (XRD)}

Sulfated zirconia modified with $\mathrm{WO}_{3}$ and $\mathrm{Ni}$ as promoters improve the catalytic activity of the isomerization process and support the catalyst stability against the rapid deactivation. The promotion of sulfated zirconia with promoters causes the change in the crystal structure accompanied by changes in the textural properties of the synthesized catalyst. Figure 4 showed the XRD pattern of the Ni-WO3/ SZ catalyst. The results showed that the presence of $\mathrm{WO}_{3}$ stabilizes zirconia, i.e. supports the tetragonal modification even at low calcination temperature. According to the obtained results, the tetragonal zirconia was about $80 \%$ and monoclinic was about $20 \%$. More stabilized tetragonal crystallite phase was obtained with $\mathrm{Ni}$ loaded as promoters to modify $\mathrm{WO}_{3}-\mathrm{SZ}$. Nickel oxide (NiO) particle inhibited the transformation of tetragonal phase to monoclinic phase at calcination stage, also, it can be seen decreasing crystallite size due to dispersed $\mathrm{NiO}$ along with modified sulfated zirconia can restrain the agglomeration of tetragonal SZ grains, besides that, there is a strong interaction between $\mathrm{NiO}$ partials and Sulfated Zirconia.

On the other hand, no diffraction peaks assigned to $\mathrm{NiO}$ can be detected, meaning the metal promoters are well dispersed in the base and have a very small crystal size $[14,15]$.

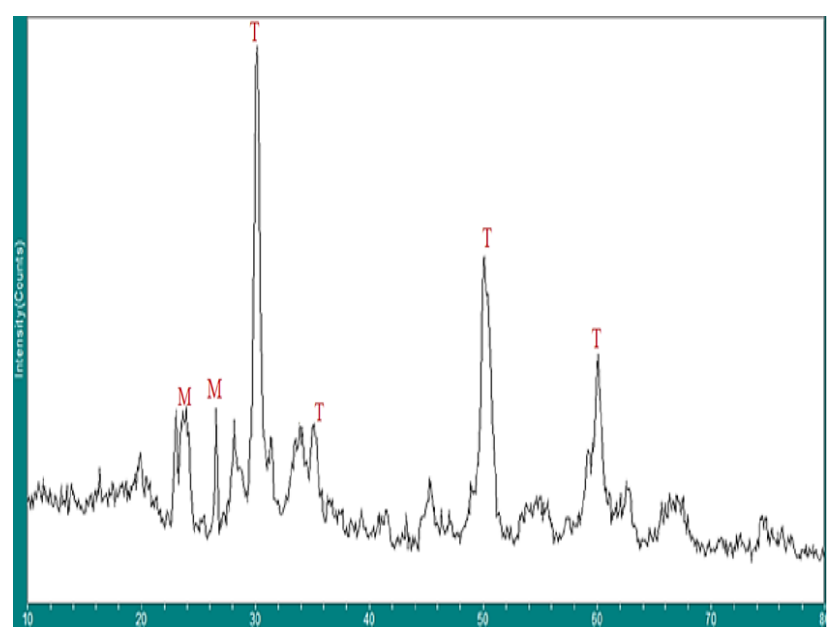

Fig. 4. XRD patterns of $\mathrm{Ni}^{-\mathrm{WO}_{3}}$ / SZ catalyst

\subsection{Fourier - Transform Infrared Spectroscopy (FTIR) Characterization}

Fig. 5 illustrates the FTIR analysis for prepared sulfated zirconia catalyst, Ni-WSZ catalyst. This technique measured the chemistry of the catalyst surface included the acidity of the active sites.

FTIR results of the study illustrated the absorption bands along the wavenumber $500-4000 \mathrm{Cm}^{-1}$, in which, the wavenumber of $500-600 \mathrm{Cm}^{-1}$ corresponded to presence $(\mathrm{Zr}-\mathrm{O}-\mathrm{Zr})$ bond, the wavenumber of (33003750) $\mathrm{Cm}^{-1}$ was corresponded to the presence the vibration of $(\mathrm{O}-\mathrm{H})$ bond, while, the absorption bond of $\mathrm{SO}_{4}^{-2}$ appears at wavenumber of $100-1500 \mathrm{Cm}^{-1}$.

This observation indicated the appearance of a covalent $(\mathrm{S}=\mathrm{O})$ double bond on the surface of sulfated groups at the catalyst which strongly affects the acidity and meets the requirement of the isomerization process.

These results were in very good agreement with other authors. Hauli et al., [16], had studied the preparation and characterization of the Sulfated Zirconia catalyst from Zirconia Nano-powder.

Their results confirm that the characterization of catalyst is highly dependent on sulfonation mechanism and calcination temperature, the results ensure that the $\mathrm{SO}_{4}{ }^{-2}$ peak would appear at a higher concentration of $\mathrm{H}_{2} \mathrm{SO}_{4}$ in sulfonating step and gradually disappear as the calcination temperature increase. 


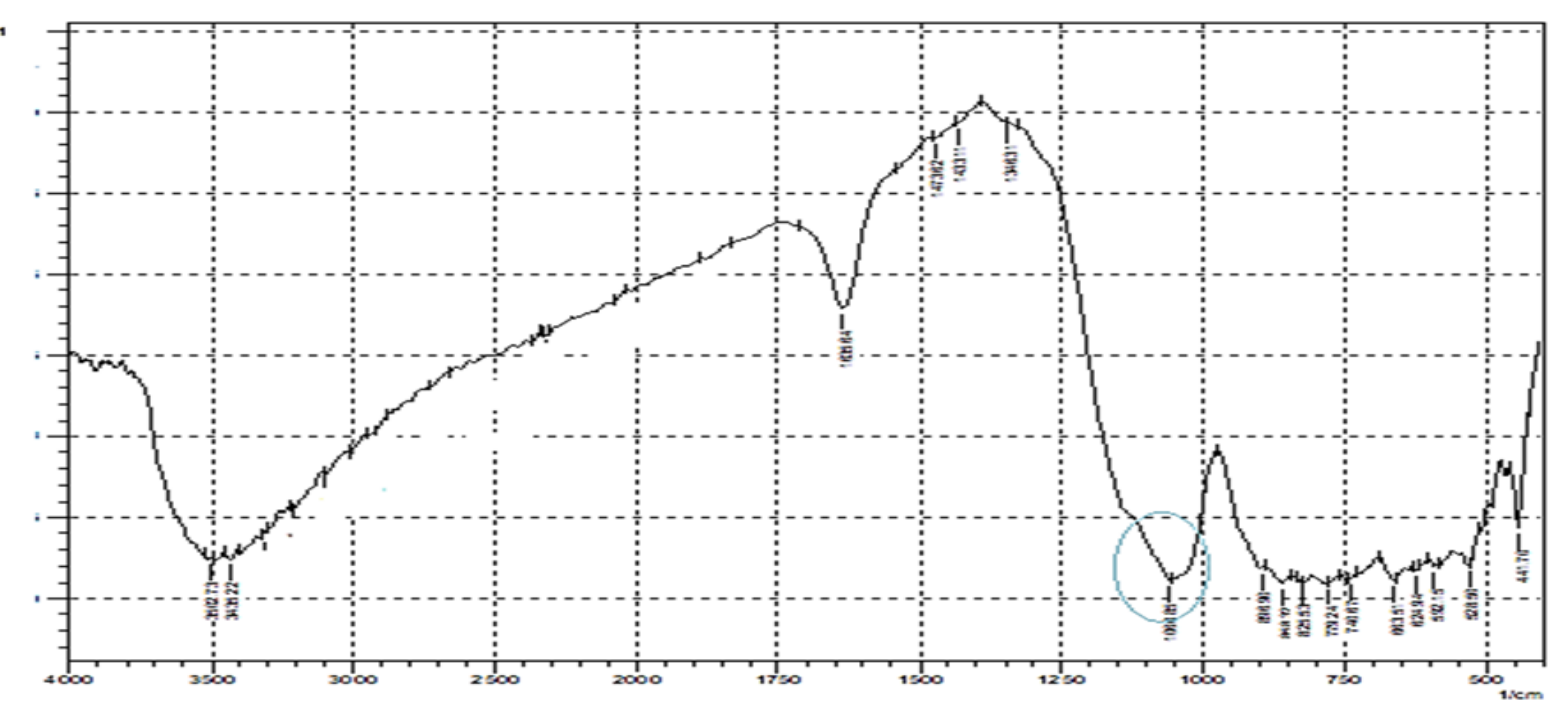

Fig. 5. FT-IR spectra of Ni-WO3/ SZ

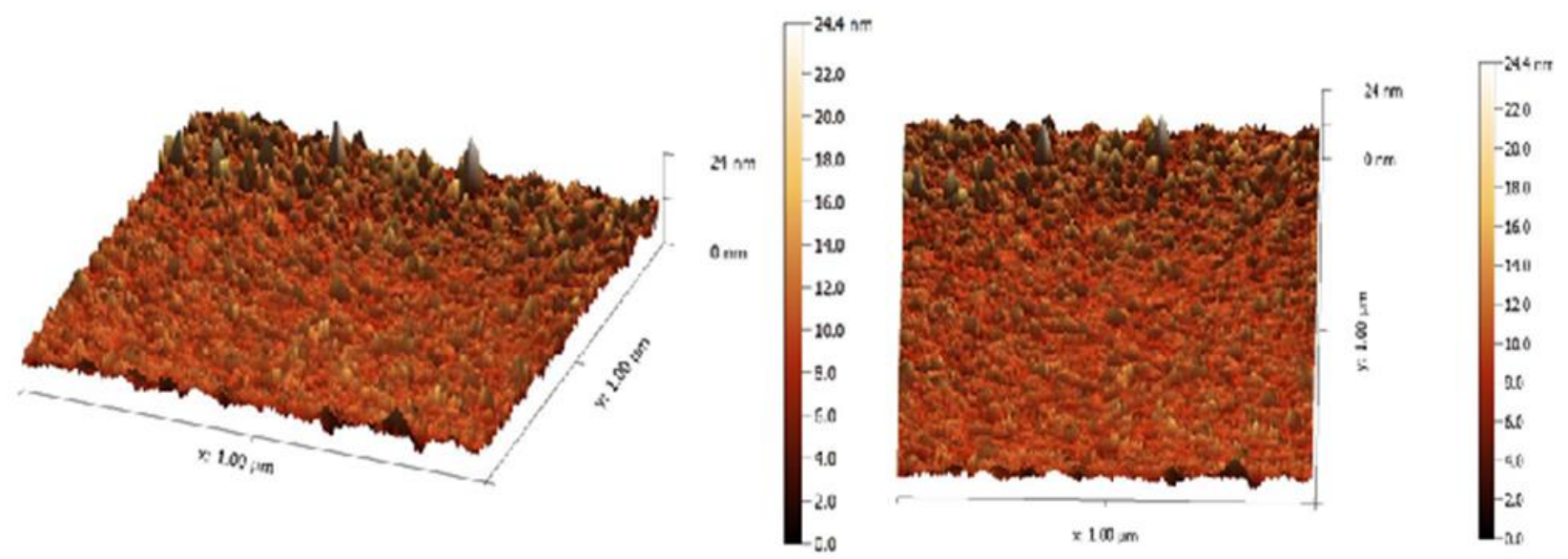

Fig. 6. 3 -D and 2-D surface profiles of $\mathrm{Ni}-\mathrm{WO}_{3} /$ modified $\mathrm{SZ}$

\subsection{Atomic Force Microscope (AFM) Characterization}

Atomic force microscopy is a powerful technique that can image almost any type of surface, it is used to measure the particle size distribution of the catalyst.

The average particle distribution after loaded metal on the catalyst, such as $\mathrm{Ni}-\mathrm{WO}_{3} /$ modified $\mathrm{SZ}$ catalyst was $9.27 \mathrm{~nm}$ with partial size dimeter range not exceeding $24.36 \mathrm{~nm} .2$ and 3 dimension of surface profiles of $\mathrm{Ni}-$ $\mathrm{WO}_{3} / \mathrm{SZ}$ as shown in Fig. 6.

The preparation mechanism affects the partial size distribution of Sulfated Zirconia catalyst, in particular, the sulfonating mechanism. Sulfate anions increase the surface area, support the stability of the tetragonal phase and minimize the crystallite size. Seen decreasing crystallite size due to dispersed $\mathrm{NiO}$ along with modified sulfated zirconia can restrain the agglomeration of tetragonal SZ grains, besides that, there is a strong interaction between $\mathrm{NiO}$ partials and Sulfated Zirconia.

\section{4- Catalysts Activity}

The experimental runs were carried out for isomerization of refinery light naphtha and n-hexane model to improve the octane number using prepared novel catalysts consisting of sulfated zirconia, as the base with its promoters $\mathrm{Ni} / \mathrm{WO}_{3} \mathrm{SZ}$.

The effect of reaction temperature $\left(130-250{ }^{\circ} \mathrm{C}\right)$ was studied, keeping other variable content, LHSV of $1 \mathrm{hr}^{-1}$, mole ration of $\mathrm{H}_{2} / \mathrm{HC}$ of 4 , and constant operation pressure of 6 bar.

4.1. $\mathrm{Ni} / \mathrm{WO}_{3} \mathrm{SZ}$ Activity for Isomerization of N-Hexane Model Fuel

Table 4 shows the chemical composition of the isomerization product by using PONA analysis to evaluate the catalyst performance. 
Table 4. PONA analysis for isomerization of n-Hexane at LHSV $=1 \mathrm{hr}-1$ and different Temperature

\begin{tabular}{lllllll}
\hline & n-hexane & $130^{\circ} \mathrm{C}$ & $150^{\circ} \mathrm{C}$ & $170^{\circ} \mathrm{C}$ & $200^{\circ} \mathrm{C}$ & $250^{\circ} \mathrm{C}$ \\
\hline n.paraffine & 99 & 35 & 20 & 27 & 36.4 & 42 \\
i-paraffine & 1 & 62 & 77 & 68.7 & 59 & 53 \\
Naphthene & 0 & 1.7 & 2 & 2.8 & 3 & 3 \\
Aromatic & 0 & 1.3 & 1 & 1.5 & 1.6 & 2 \\
\hline
\end{tabular}

\section{a. n-paraffin Conversion}

The results are illustrated in figure 7 , which represents the n-paraffin conversion as a function of operating temperature. The conversion of n-paraffin to i-paraffin, naphthene, and aromatic compounds was started at 130 ${ }^{\circ} \mathrm{C}$ in many different proportions toward i-paraffin Thereafter, it keeps up from $65 \%$ to $80 \%$ at $150{ }^{\circ} \mathrm{C}$, which represents the maximum conversion obtained in this set of research. Then, it decreases to $73 \%, 63.6 \%$, and $58 \%$ at $170^{\circ} \mathrm{C}, 200^{\circ} \mathrm{C}$, and $250{ }^{\circ} \mathrm{C}$ respectively.

The results of this research are good and encouraging start in the field of petroleum research that uses a significant acid-grade catalyst that matches the requirement of the process at mild conditions as discussed later with other accompanying conditions.

The maximum conversion achieved was $80 \%$ that represents one of the highest degrees as compared with other researchers that used Zirconia-based catalyst.

M. Busto et. al. [18] discovered new paraffin isomerization catalysts based on $\mathrm{Pt} / \mathrm{SZ}$, maximum conversion achieved of about $95 \%$ at $230{ }^{\circ} \mathrm{C}$. Torres et.al. [19], studied modification of $\mathrm{WO}_{3}-\mathrm{ZrO}_{2}$ catalyst by metal addition, maximum conversion achieved was about $70 \%$. Ma et.al.[11], studied Pd-Ni doped Sulfated Zirconia for isomerization of n-Hexane, maximum conversion achieved was about $70 \%$.

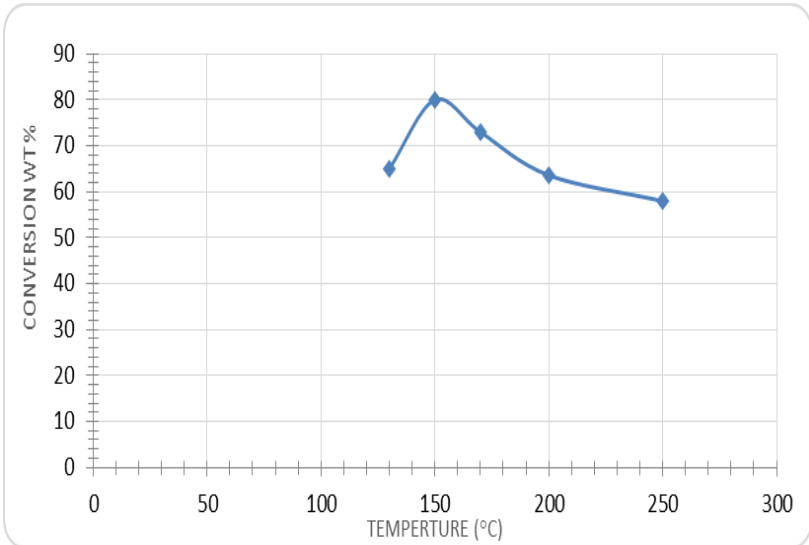

Fig. 7. Effect of temperature on isomerize conversion of n-hexane over $\mathrm{Ni}-\mathrm{WO}_{3} / \mathrm{SZ}$ b. i-paraffins, naphthenes, and aromatic Selectivity and Yield

Operation temperature has a major impact on the isomerization process, in particular, on the conversion of the feed to isomer product and its accompanied naphthenes and aromatic and others when the temperature exceeds the limits of isomerization process. Fig. 8 and Fig. 9 illustrate the effect of temperature on isomer compounds, naphthenes, and aromatic selectivity and yields. The results indicate that the isomer's selectivity begins with a maximum degree of $96 \%$ at $150{ }^{\circ} \mathrm{C}$ and went on with a slight decrease to meet $90 \%$ at $250{ }^{\circ} \mathrm{C}$. At the same time, naphthenes were detected at $130{ }^{\circ} \mathrm{C}$ with a $2.6 \%$ with a slight increase of only $5.1 \%$ at $250{ }^{\circ} \mathrm{C}$. Also, aromatic compounds were detected with $2 \%$ at $130{ }^{\circ} \mathrm{C}$ and a slight increase reaching $3.4 \%$ at $250{ }^{\circ} \mathrm{C}$. Also, the results indicate that the isomers yield begins with a maximum degree of $77 \%$ at $150{ }^{\circ} \mathrm{C}$ and went on with decreased to reach $53 \%$ at $250{ }^{\circ} \mathrm{C}$. At the same time, naphthenes were detected at $130{ }^{\circ} \mathrm{C}$ with $1.7 \%$ with a slight increase of only $3 \%$ at $250{ }^{\circ} \mathrm{C}$. Also, aromatic compounds were detected with $1.3 \%$ at $130{ }^{\circ} \mathrm{C}$ and a slight increase reaching $2 \%$ at $250{ }^{\circ} \mathrm{C}$. These results with mild conditions accompanied the operation refers to the suitable catalyst used and isomerization operation conditions.

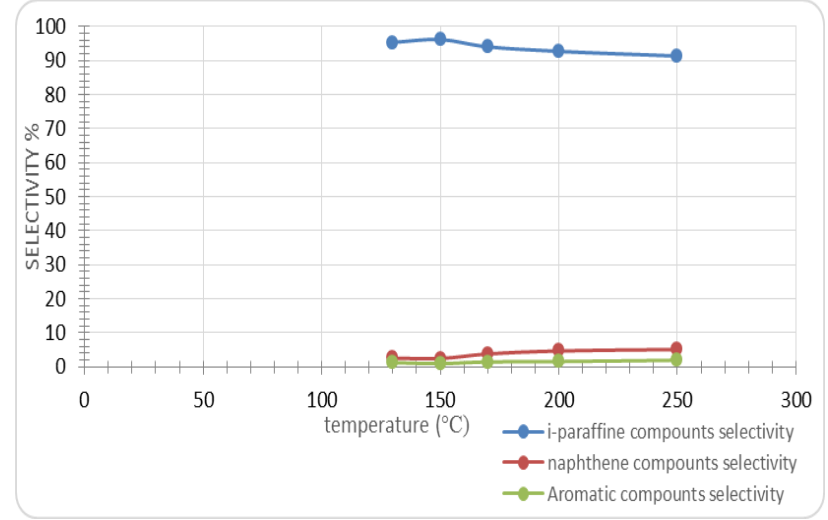

Fig. 8. Effect $f$ temperature on the selectivity of iparaffins, naphthenes, and aromatic compounds over Ni$\mathrm{WO}_{3} / \mathrm{SZ}$ catalyst

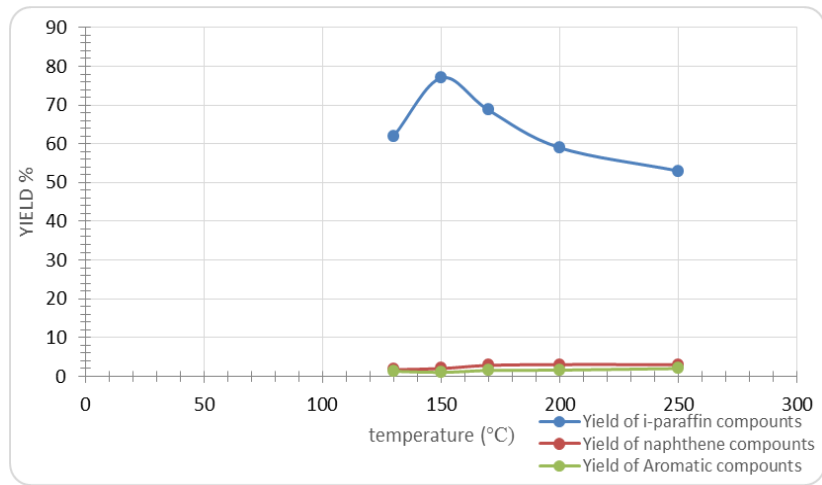


Fig. 9. Effect of temperature on yield of i-paraffins, naphthenes, and aromatic compounds over $\mathrm{Ni}-\mathrm{WO}_{3} / \mathrm{SZ}$ catalyst from n-hexane feed

4.2 $\mathrm{Ni}-\mathrm{WO}_{3} / \mathrm{SZ}$ Activity for Isomerization of Light Naphtha

Table 5 shows the chemical composition of the isomerization product by using PONA analysis to evaluate the catalyst performance.

Table 5. PONA analysis for isomerization of Iraqi light naphtha at LHSV $=1 \mathrm{hr}-1$ and constant pressure 6 bar

\begin{tabular}{|c|c|c|c|c|c|c|}
\hline & L.N & $130^{\circ} \mathrm{C}$ & $150^{\circ} \mathrm{C}$ & $170^{\circ} \mathrm{C}$ & $200^{\circ} \mathrm{C}$ & $250^{\circ} \mathrm{C}$ \\
\hline n.paraffine & 56.33 & 43 & 26.4 & 37.7 & 40.7 & 42.5 \\
\hline i-paraffine & 33 & 41 & 49.5 & 45.2 & 41.5 & 37.2 \\
\hline Naphthene & 6.78 & 9 & 13.9 & 11.4 & 9.6 & 10.8 \\
\hline Aromatic & 4 & 7 & 10.1 & 5.9 & 9 & 10 \\
\hline
\end{tabular}

\section{a. Light Naphtha (n-paraffin) Conversions}

The results obtained here indicate that the conversion of n-paraffin started at $130{ }^{\circ} \mathrm{C}$ with $23.7 \%$ and reached its maximum value at $150{ }^{\circ} \mathrm{C}$ with $53 \%$. Hereafter, the conversion was slightly reduced to meet $24.5 \%$ at $250{ }^{\circ} \mathrm{C}$ as shown in Fig. 10. These expected results are in agreement with other authors, due to all the conditions related to the preparation of the catalyst on one side, and to the operational conditions on the other side, as well as, the massive competition of the molecules included the light naphtha composition, i.e., i-paraffines, naphthenes, and aromatics, besides, the intermediate compounds formed during the reactions which largely affected the acidity active sites of the catalysts.

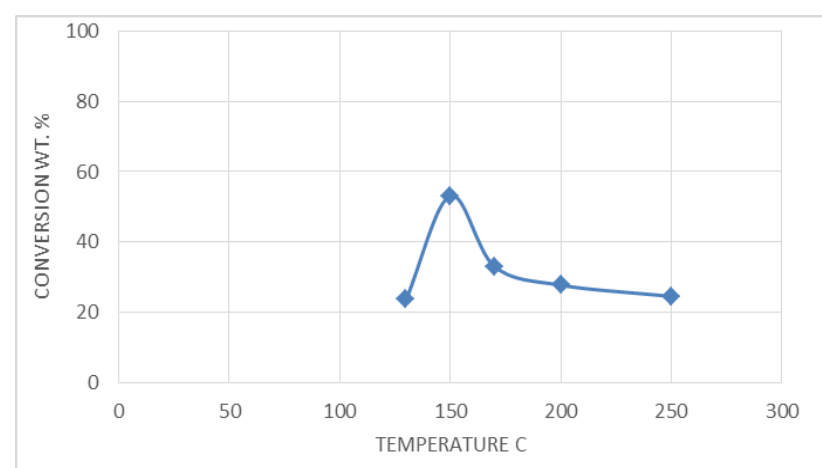

Fig. 10. Effect of temperature on isomerization conversion of light naphtha over $\mathrm{Ni}-\mathrm{WO}_{3} / \mathrm{SZ}$ catalyst

b. i-paraffins, naphthenes, and aromatic Selectivity and Yield

In general, catalytic operations are so complex it depends on many variables, catalyst characterization, petroleum fractions, and their compositions, and the operating conditions the results of this set of experiments observed the presence of naphthenes, and aromatics compounds besides the isomers compounds.
The selectivity to isomers started to increase at $130{ }^{\circ} \mathrm{C}$ with the value of $72 \%$ and reach the maximum at $150 \mathrm{C}$ with $74 \%$, hereafter; the selectivity began to reduce and had $72 \%, 68 \%$, and $64 \%$ at $170{ }^{\circ} \mathrm{C}, 200{ }^{\circ} \mathrm{C}$, and $250{ }^{\circ} \mathrm{C}$ respectively. This behavior was in agreement with other anthers due to the presence of many intermediate compounds that affect the acidic active sites of the catalyst.

Also, the results showed that the presence of naphthenes during the reaction, the selectivity $15 \%, 19 \%, 18 \%, 16 \%$, and $18 \%$ was at $130^{\circ} \mathrm{C}, 150^{\circ} \mathrm{C}, 170{ }^{\circ} \mathrm{C}, 200^{\circ} \mathrm{C}, 250^{\circ} \mathrm{C}$ respectively, and the aromatic compounds with the selectivity of $12 \%, 14 \%, 9 \%, 15 \%$, and $17 \%$ at the above operating temperature respectively. This appearance was due to the conversion of $n$-paraffin to i-paraffin, naphthene, aromatics besides the various behaviors expected by the specialist authors in this field.

Fig. 11 and Fig. 12 illustrate the effect of temperature on isomer compounds, naphthenes, and aromatic selectivity and yields.

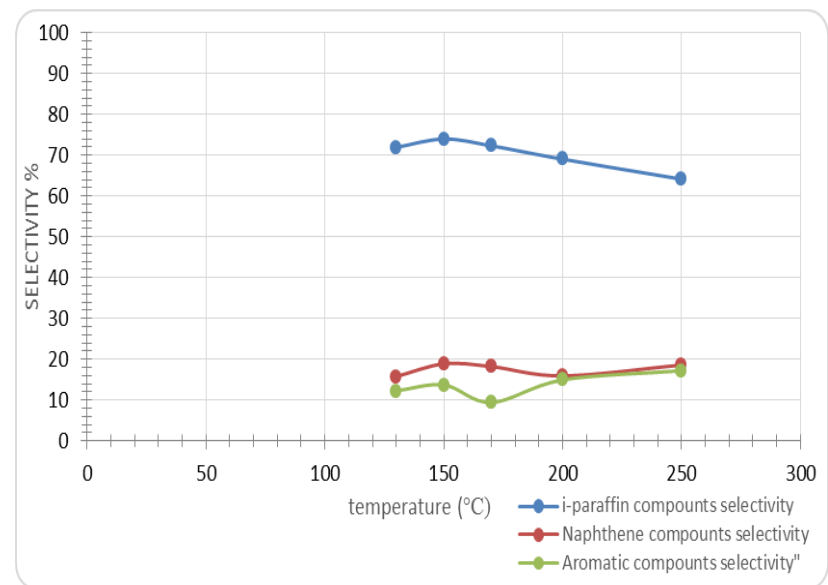

Fig. 11. Effect of temperature on selectivity of i-paraffins, naphthenes, and aromatic compounds over Ni$\mathrm{WO}_{3} /$ modified SZ catalyst from light naphtha

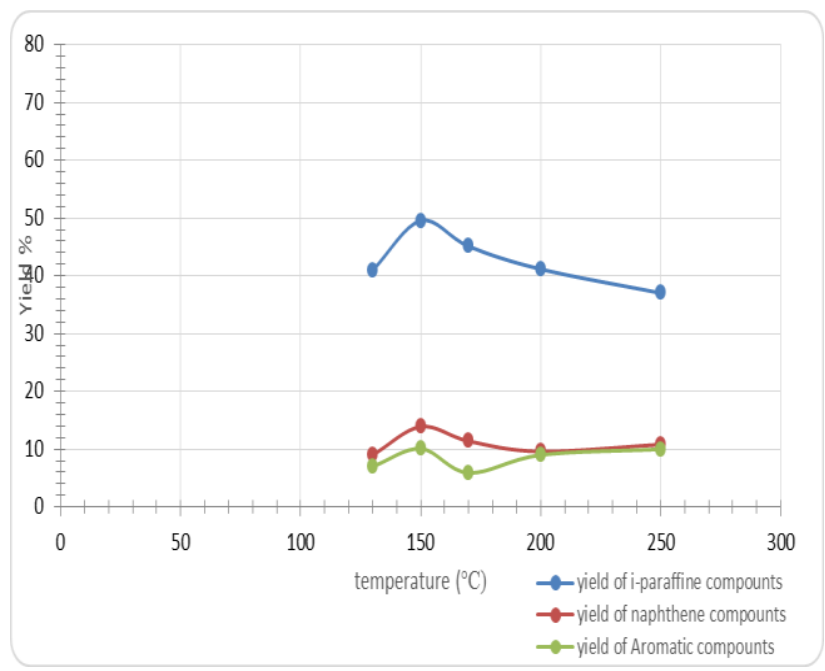


Fig. 12. Effect of temperature on Yield of i-paraffins, naphthenes, and aromatic compounds over Ni$\mathrm{WO}_{3} /$ modified SZ catalyst from light naphtha

Many studies have tried to determine the nature of the acidity active sites (Bronsted and/or lewis) on the catalyst surface and the mechanism to obtain them. They found that this matter depends on water content, which depends strongly on the preparation method and its conditions [20].

On the other side, the presence of promoters was found to have a great effect in improving the performance of the catalyst. Sulfated Zirconia likes another solid acidic catalyst suffers rapid deactivation during hydrocarbon reactions due to the formation of other side reaction production, in particular, coke formation. The addition of some transition metals, i.e., Ni to the SZ catalyst resulted in a great improvement to the catalyst performance. This was observed from the results of the isomerization process to n-hexane and the refinery light naphtha under mild conditions, which have shown high activity towards isomer compounds.

The addition of $\mathrm{Ni}$ and $\mathrm{WO}_{3}$ to sulfated zirconia improved the performance of the catalyst towards high nparaffins conversion, isomer compound formation, and diminish coke appearance as a cracking reaction. Many authors studied and discussed this behavior; they related the phenomena to the dependence of chemical reaction activation energy on the enthalpy of transition state complex formation on the catalyst surface, so the activity of such catalyst depends on the lower value of enthalpy [21].

The effect of hydrogen in the isomerization reaction over the SZ catalyst depends on the mechanism of the nparaffin reactions. For the n-paraffins of light naphtha, the hydrocarbon reaction, i.e., isomerization reaction and/or cracking follow a monomolecular mechanism. So the effect of hydrogen will be positive[22].

\section{5- Conclusion}

It is found that Sulfated zirconia is considered to be a very important base catalyst throughout its acidic actives that match the requirement of the isomerization process of n-hexane and light naphtha. Isomerization of alkanes in the presence of sulfated zirconia catalysts needs mild conditions of operating temperature of about $150^{\circ} \mathrm{C}$ and pressure of about 6 bar. Ni-WSZ gives a high conversion at these conditions of about $80.1 \%$, while the selectivity of isomers of about $96 \%$.

\section{References}

[1] Aboul-Gheit, A.K., El-Desouki, D.S., Abdel-Hamid, S.M., Ghoneim, S.A., Ibrahim, A.H., Gad, F.K., (2012). "Sulfated zirconia catalysts for low temperature isomerization of n-pentane". Egypt. J. Chem. 55, 509-527.

[2] Mohamed, M. F., Shehata, W. M., Halim, A. A., and Gad, F. K. (2017) "Improving gasoline quality produced from MIDOR light naphtha isomerization unit", Egyptian Journal of Petroleum, 26(1), pp. 111124.

[3] Aljandeel H.A., Hussein H.Q.," Kinetic Study of Hydroisomerization of n-Decane using Pt/SAPO- 11 catalysts", Iraqi Journal of Chemical and Petroleum Engineering 2018, 19(3), 11-17.

[4] Aljandeel H.A., Hussein H.Q.," Advanced Study of $\begin{array}{llll}\text { Promoted Pt } & \text { /SAPO-11 } & \text { Catalyst for }\end{array}$ Hydroisomerization of the n-Decane Model and Lube Oil ", Iraqi Journal of Chemical and Petroleum Engineering 2021, 22(2), 17-26.

[5] $\mathrm{Vu}, \mathrm{T}$. N. et al. (2005), "Platinum-tungstated zirconia isomerization catalysts: Part II. Effect of platinum and tungsten loading on the mechanism of isomerization of n-hexane: A kinetic study", Journal of Catalysis, 231(2), pp. 468-479.

[6] Fa rcas iu, D. and Li, J. Q. (1995) 'Preparation of sulfated zirconia catalysts with improved control of sulfur content', Applied Catalysis A, General, 128(1), pp. 97-105.

[7] Abudawood, R. H. (2010),"Hydroisomerization of alkane over metal-loaded zeolite catalysts" ,Chemical Engineering and Analytical Science", Ph.D. thesis, University of Manchester

[8] Wang, P., Yue, Y., Wang, T., Bao, X. (2020) "Alkane isomerization over sulfated zirconia solid acid system", International Journal of Energy Research, 44(5), pp. 3270-3294.

[9] $\mathrm{Li}, \mathrm{X}$. (2004) ,Butane skeletal isomerization on sulfated zirconia at low temperature". Thesis, Faculty of Chemistry at the Technical University of Munich,German

[10] Liu, N. et al. (2020), "Palladium-doped sulfated zirconia: Deactivation behavior in isomerization of nhexane", Fuel, 262, p. 116.

[11] Ma, Z., Meng, X., Liu, N., Shi, L., (2018). "Ni doped sulfated zirconia: Study of hydrogen spillover and isomerization of N-hexane". Mol. Catal. 449, $\underline{114-121 .}$.

[12] Shkurenok, V.A., Smolikov, M.D., Yablokova, S.S., Kiryanov, D.I., Belyi, A.S., Paukshtis, E.A., Leonteva, N.N., Gulyaeva, T.I., Shilova, A. V., Drozdov, V.A., (2015)," Pt/WO3/ZrO2 catalysts for nHeptane isomerization". Procedia Eng. 113, 62-67.

[13] Kamel S.A. , Al-jendeel , Mohammed W.T., 2021, "Preparation of Solid-Super Acidic Catalyst with Improvement Physical Properties", Materials Science Forum, Vol. 1039, pp 313-325.

[14] Dzhikiya, O. V., Smolikov, M.D., Kazantsev, K. V., Yablokova, S.S., Podmareva, O.E., Belyi, A.S., (2019). "The effect of palladium addition to sulfated zirconia catalysts on physicochemical and catalytic properties in the n-hexane isomerization reaction". AIP Conf. Proc. 2141.

[15] Smolikov, M. D. et al. (2019) "Active surface formation of tungstated zirconia catalysts for nheptane isomerization", Catalysis Today, 329(July 2018), pp. 63-70. 
[16] Hauli, L., Wijaya, K., Armunanto, R., (2018). "Preparation and characterization of sulfated zirconia from a commercial zirconia nanopowder". Orient. J. Chem. 34, 1559-1564.

[17] Aboul-Gheit, A.K., El-Desouki, D.S., AbdelHamid, S.M., Ghoneim, S.A., Ibrahim, A.H., Gad, F.K., 2012. Sulfated zirconia catalysts for low temperature isomerization of n-pentane. Egypt. J. Chem. 55, 509-527.

[18] M. BustoL .A.DossoC.R.VeraJ.M.Grau ,(2012), Composite catalysts of $\mathrm{Pt} / \mathrm{SO} 42--\mathrm{ZrO} 2$ and $\mathrm{Pt} / \mathrm{WO} 3-$ $\mathrm{ZrO} 2$ for producing high octane isomerizate by isomerization-cracking of long paraffins, Fuel Processing Technology Volume 104, December 2012, Pages 128-135.

[19] Torres, G.C., Manuale, D.L., Benítez, V.M., Román, C., Carlos, J., 2012. MODIFICATION OF THE PERFORMANCE OF WO3-ZrO2 CATALYSTS BY METAL ADDITION IN HYDROCARBON REACTIO Artigo 35, 748-754.

[20] Hsu C.Y., Heimbuch C.R., Armes C.T. , Gates B.C., (1992)," A highly active solid superacid catalyst for n-butane isomerization: a sulfated oxide containing iron, manganese and zirconium", J. Chem. Soc. Chem. Commun, 22,p.p. 1645-1646.

[21] Sadoon Ahmedzeki, N., \& Salah Alddin Mahdi, A. (2014). Research Octane Number Improvement of Iraqi Gasoline by Adsorption of n-Paraffins Using Zeolite Molecular Sieves. Iraqi Journal of Chemical and Petroleum Engineering, 15(2), 27-37.

[22] Singhal, S., Agarwal, S., Kumar, A., 2019. Isomerization of lighter alkanes by heteropoly acids : A review. J. Catal. Catal. 2, 1-14. 


\title{
تصنيع وتثخيص العامل المساعد النانوي الزركونيا المكبرتة المحملة بالنيكل واوكسيا التنكستن لازمرة الكهسان والنفثا العراقية الخفيفة
}

\author{
صفا عبد السلام كامل , ودود طاهر محمد و حيدر عبد الكريم رشيد
}

جامعة بغداد/كلية المنسسة

الخلاصة

تم تحضيرمحفز الزركونيا المكبرتة (SZ) لازمرة الهكسان والنفتا الخفيفة و تطويرهما , بالاضافة الى التدعيم ببعض المعادن للحصول على الظروف المعتدلة والاستقرارية ومنع تكون الفحم على المواقع الحامضية في العامل المساعد. تم توصيف جميع محفزات التقليدية والمعدلة بواسطة التحليل الطيفي للاشعة تحت الحمراء , الاشعة السينية Brunauer -Emmett-Teller (BET) , XRD , FTIR التحلل الحراري الوزني TGA , تحليل الذري المجهري AFM. اظهرت النتائج أن الحد الأقصى للتحويل والإنتاجية لأزمرة الهكسان على Ni-WSZ بدرجة حرارة 150ْم هي 80,1 \% و 96\% على التوالي. اما باقي التجارب مع النفتا الخفيفة فقد اظهرت ان اعلى نسبة تحول والانتاجية على الالعامل المساعد Ni-WSZ وفي درجة حرارة 150ْم هي 53 \% و 74\% على التوالي.

الكلمات الدالة : النفثا الخفيفة, الهكسان, نيكل-تنكستن, الازمرة , الزركونيا المكبرتة 